\title{
Relative Humidity Influences Yield, Edible Biomass, and Linear Growth Rate of Sweetpotato
}

\author{
D.G. Mortley', C.K. Bonsi ${ }^{2}$, P.A. Loretan ${ }^{2}$, W.A. Hill' ${ }^{2}$, and C.E. Morris ${ }^{3}$ \\ George Washington Carver Agricultural Experiment Station, Tuskegee \\ University, Tuskegee, AL 36088
}

Additional index words. Ipomoea batatas, nutrient film technique, hydroponics, photosynthesis

\begin{abstract}
Growth chamber experiments were conducted to study the physiological and growth response of sweetpotato [Ipomoea batatas (L.) Lam.] to either $50 \%$ or $85 \%$ relative humidity (RH). Vine cuttings of T1-155 were grown using the nutrient film technique in a randomized complete-block design with two replications. Temperature regimes of 28/ 22C were maintained during the light/dark periods with irradiance at canopy level of 600 $\mu \mathrm{mol} \cdot \mathrm{m}^{-2} \cdot \mathrm{s}^{-1}$ and a $14 / 10$-hour photoperiod. High $\mathrm{RH}(85 \%)$ increased the number of storage roots per plant and significantly increased storage root fresh and dry weight, but produced lower foliage fresh and dry weight than plants grown at $50 \% \mathrm{RH}$. Edible biomass index and linear growth rate (in grams per square meter per day) were significantly higher for plants grown at $85 \%$ than at $50 \% \mathrm{RH}$. Leaf photosynthesis and stomatal conductance were higher for plants at $85 \%$ than at $50 \% \mathrm{RH}$. Thus, the principal effect of high RH on sweetpotato growth was the production of higher storage root yield, edible biomass, growth rate, and increased photosynthetic and stomatal activity.
\end{abstract}

Studies on relative humidity $(\mathrm{RH})$ effects on growth of root and tuber crops are few. Wheeler et al. (1 989) reported that three potato (Solarium tuberosum L.) cultivars grown at high RH (85\%) produced increased tuber yields compared to plants grown at lower RH $(50 \%)$, while leaf area was greater at the lower $\mathrm{RH}$ level. Crop plants, including lettuce (Lactuca sativa L.) (Tibbitts and Bottenburg, 1976), wheat (Triticum aestivum L.), sugarbeet (Beta vulgaris L.), and kale (Brassica oleracea L.) (Ford and Theme, 1973), have all responded positively to increased $\mathrm{RH}$. We are not aware of any information in the literature evaluating sweetpotato response to $\mathrm{RH}$.

Research on growth responses of food crops under controlled environment conditions is currently being conducted by the U.S. National Aeronautics and Space Administration (NASA) for long-term manned space missions through its controlled ecological life support systems (CELSS).

Sweetpotatoes have been grown hydro-

Received for publication 7 Dec.1992. Accepted for publication 31 Oct. 1993. Contribution no. 228 of the George Washington Carver Agricultural Experiment Station,TuskegeeUniv.Thisresearchwas supported by funds from NASA(grant no.NAG 100024) and U.S. Dept. of Agriculture/Cooperative State Research Service (grant no. ALx-SP-1). We thank Raymond Wheeler, Ralph Prince (recently retired), and William Knott of the NASA/John F. Kennedy Space Center for their technical assistance. The cost of publishing this paper was defrayedinpartby the payment of page charges.Under postal regulations, this paper therefore must be herebymarked advertisement solelytoindicate this fact.

'Research Assistant Professor.

${ }^{2}$ Professor.

${ }^{3}$ Associate Professor. ponically (Hill et al., 1989) using the nutrient film technique (NFT) that might be applied for a CELSS. Information gained from this study will add to NASA's overall objective of food production for long-duration space flights.

Our objective was to determine the effects of RH on storage root yield, edible biomass index (EBI), linear growth rate, and physiological response of sweetpotato in NFT.

Vine cuttings ( $0.15 \mathrm{~m}$ long) of T1-155 sweetpotato were grown in $0.15 \times 0.15 \times 1.2$ m NFT channels (Morns et al., 1989) in controlled-environment, walk-in growth chambers (Conviron model PGW 36; Conviron Products of America, Ashville, N.C.). A randomized complete-block design with either $50 \%$ or $85 \%$ RH (actual RH averaged $52 \%$ and $84 \%$, respectively) and four replications (with three channels per treatment) in time was used. A mixture of cool-white fluorescent and incandescent lights provided photosynthetic photon flux at canopy level of $600 \mu \mathrm{mol} \cdot \mathrm{m}^{-2} \cdot \mathrm{s}^{-1}$.A modified half-Hoagland (Hoagland and Arnon, 1950 ) solution provided a $1 \mathrm{~N}: 2.4 \mathrm{Kratio}$, and solution $\mathrm{pH}$ was maintained between 5.5 and 6.0 by adding either dilute $\mathrm{NaOH}$ or $\mathrm{HO}_{2} \mathrm{SO}_{4}$. The nutrient solution was changed every 2 weeks and was continuously pumped from each reservoir at 1 liter. $\mathrm{min}^{-1}$ to the high end of each channel by small magnetic drive pumps (Little Giant model 2P037; Tecumseh Products Co., Oklahoma City, Okla.). Each vine cutting, spaced $0.25 \mathrm{~m}$ within channels that were spaced $0.25 \mathrm{~m}$ apart (Mortley et al., 1991), was held in place by a flat-plate assembly (Morns et al., 1989) attached to the sides of the channel by a flexible white-black vinyl covering.

The photoperiod in the chambers was set for 14-h light and 10-h dark periods, with temperatures at $28 / 22 \mathrm{C}$, respectively. Photosynthesis (between 1100 and 1400 HR), leaf temperature, and stomatal conductance data were collected over five consecutive days, beginning 81 days after planting, from the fourth fully opened leaf at the vine's end at the top of the canopy by using a LI-6200 portable photosynthesis system (LI-COR, Lincoln, Neb.).

Plants were harvested at 120 days, and all foliage was cut at the plant's base, weighed fresh, and dried for $48 \mathrm{~h}$ at 70C. A composite $25-\mathrm{g}$ sample of storage roots from each of four plants per growth channel was dried at $70 \mathrm{C}$ for $48 \mathrm{~h}$. This information was used to calculate a fresh weight to dry weight conversion factor that was then used to convert measured fresh weight to determine storage root dry weight. EBI (storage root mass/total plant mass) x 100 and linear growth rates (in grams per square meter per day) were determined. Four runs of the experiment were conducted, and each time chambers were switched to minimize chamber effects. Data were combined by treatment and analyzed by t test (paired comparison), with pairing done on the basis of the two growth chambers.

Plants grown under $85 \% \mathrm{RH}$ produced about one more storage root per plant than plants grown under 50\% RH (Table 1). Storage root fresh and dry weight per plant were $29 \%$ and $25 \%$ higher, respectively, under $85 \%$ RH than $50 \%$ RH. Foliage fresh and dry weights were lower when plants were grown under

Table 1. Growth and physiological responses of sweetpotato (Ipomoea batatas) at different humidity levels.

\begin{tabular}{|c|c|c|c|}
\hline \multirow[b]{2}{*}{ Growth responses } & \multicolumn{2}{|c|}{$\mathrm{RH}(\%)$} & \multirow[b]{2}{*}{$P$ values $^{2}$} \\
\hline & 50 & 85 & \\
\hline \multicolumn{4}{|l|}{ Storage root } \\
\hline No. per plant & 4.8 & 6.0 & 0.10 \\
\hline Fresh weight (g/plant) & 668 & 861 & 0.001 \\
\hline Dry weight (g/plant) & 124 & 155 & 0.001 \\
\hline \multicolumn{4}{|l|}{ Foliage } \\
\hline Fresh weight & 646 & 582 & 0.10 \\
\hline Dry weight & 81.4 & 72.4 & 0.10 \\
\hline $\mathrm{EBI}(\%)^{y}$ & 56.5 & 63.7 & 0.001 \\
\hline Growth rate $\left(\mathrm{g} \cdot \mathrm{m}^{-2} \cdot\right.$ day $\left.^{-1}\right)$ & 22.4 & 27.8 & 0.001 \\
\hline Leaf temperature $\left({ }^{\circ} \mathrm{C}\right)$ & 33.2 & 31.9 & 0.001 \\
\hline $\operatorname{Pn}\left(\mu \mathrm{mol} \mathrm{CO} \mathrm{CO}_{2} / \mathrm{m}^{2} \text { per sec }\right)^{x}$ & 3.5 & 9.3 & 0.05 \\
\hline Stomatal conductance $\left(\mathrm{mol} \cdot \mathrm{m}^{-2} \cdot \mathrm{s}^{-1}\right)$ & 0.37 & 1.65 & 0.05 \\
\hline
\end{tabular}

${ }^{2}$ Significant at $0.10,0.05$, or 0.001 .

${ }^{\mathrm{y}} \mathrm{EBI}=$ edible biomass index

${ }^{\times} \mathrm{Pn}=$ rate of photosynthesis. 
$85 \% \mathrm{RH}$ when compared to plants grown at $50 \% \mathrm{RH}$ (Table 1). EBI and linear growth rate were significantly higher for plants grown at $85 \%$ than at $50 \% \mathrm{RH}$ (Table 1 ). These values for EBI are similar to those of sweetpotato grown in the field (Bhagsari and Ashley, 1990), potato grown under controlled conditions, and lettuce, but exceeded those for wheat and soybean (Glycine max L.) (Bugbee and Salisbury, 1988; SalisburyandBugbee, 1988). High sweetpotato EBI indicates that storage roots constituted the main sink for photosynthates (Bhagsari and Ashley, 1990). High EBI is especially critical for CELSS because it means there would be less nonedible mass to be processed as waste.

Plants grown under 50\% RH exhibited higher leaf temperatures than did those of plants grown at $85 \% \mathrm{RH}$ (Table 1).

Single leaf photosynthesis (Pn) was consistently higher for plants grown at $85 \% \mathrm{RH}$ than at $50 \%$ RH. Stomatal conductance (Table 1) was higher at $85 \%$. than at $50 \% \mathrm{RH}$.

Increased $\mathrm{RH}$ under the conditions in this study enhanced sweetpotato storage root yield, edible biomass, and growth rate. Increased growth under high $\mathrm{RH}$ may result either from increased stomatal conductance and thus increased $\mathrm{CO}_{2}$ uptake (Slavik, 1973) or from increased cell enlargement (which provides a large leaf area for light absorption), or from combined increases in stomatal conductance and cell enlargement (Hoffman et al., 1971). Also in sweetpotatoes, as shown for potatoes (Wheeler et al., 1989), the high RH favored allocation of photosynthates to storage tissues over foliage.

\section{Literature Cited}

Bhagsari, A.S. and D.A. Ashley. 1990. Relationship of photosynthesis and harvest index to sweetpotato yield. J. Amer. Soc. Hort. Sci. 115:288-293.

Bugbee, B.G. and F.B. Salisbury. 1988. Exploring the limits of crop productivity: Photosynthetic efficiency of wheat in high irradiance environments. Plant Physiol. 88: 869-878.

Ford, M.A. and G.N, Theme. 1973. Effects of atmospheric humidity on plant growth. Ann. Bet. $38: 441-452$.

Hill, W. A., P.A. Loretan, C.K, Bonsi, C.E. Morris, J.Y. Lu, R.D. Pace, and C.R Ogbuehi. 1989. Utilization of sweetpotato in controlled ecological life support systems (CELSS). Adv. Spec. Res. 9:29-41.
Hoagland, D.R. and D.L Amen, 1950. The waterculture method for growing plants without soil. Calif. Agr. Expt. Sta. Circ. 347.

Hoffman, G.J., S.L. Rawlins, M.J. Garber, and E.M. Cullen. 1971. Water relations and growth of cotton as influenced by salinity and relative humidity. Agron. J. 63:822-826.

Morns, C. E., P.A. Loretan, C.K. Bonsi, and W.A. Hill. 1989. Moveable root contact pressure plate assembly for hydroponic system. U.S. Patent 4,860,490. Issued 29 Aug. 1989.

Mortley,D.G., P.A. Loretan, C.K. Bonsi, W.A. Hill, and C.E. Morris. 1991, Plant spacing influences yield and linear growth rate of sweetpotatoes grownhydroponically.HortScience26:1274-1275.

Salisbury, F.B. and B. Bugbee. 1988. Plant productivity in controlled environments. HortScience 23:293-299.

Slavik, B. 1973. Transpiration resistance in leaves of maize grown in humid and dry air, p. 267269, In: R.O. Slayter (cd.). Plant response to climatic factors. United Nations Educ. Scientific and Cultural Organization. Placede Fontenay, Paris.

Tibbitts, T.W. and G. Bottenberg. 1976. Growth of lettuce under controlled humidity levels.J.Amer. Soc. Hort. Sci. 101:70-73.

Wheeler, R.M., T.W. Tibbitts, and A.H. Fitzpatrick. 1989. Potato growth in response to relative humidity. HortScience 24:482484. 